\title{
Immunohistochemical detection of human cytomegalovirus, Epstein-Barr virus and human papillomavirus in invasive breast carcinoma in Egyptian women: A tissue microarray study
}

\author{
Rehab A Ahmed; Shaimaa M Yussif \\ Pathology Department, Faculty of Medicine, Mansoura University, Mansoura, Egypt
}

Received: Feburay 11, 2016

DOI: $10.5430 /$ jst.v6n2p8
Accepted: March 22, 2016

Online Published: March 30, 2016

\begin{abstract}
Background and aim: Breast cancer is the commonest malignant tumor and a common cause of cancer death in women all over the world. Some recent studies attributed breast cancer to viral infection. This study aimed to evaluate the expression of HCMV, EBV and HPV in invasive carcinoma of the breast among the Egyptian women by immunohistochemistry and whether there is a relationship between the prognostic factors of breast carcinoma and these viruses.

Patients and methods: This retrospective study included 107 selected cases of invasive breast carcinoma. Slides cut from tissue microarray prepared blocks were stained immunohistochemically for HCMV, EBV and HPV antigens. The association of such viruses with the clinicopathological features, tumor recurrence and patient death was evaluated statistically.

Result: HCMV, EBV and HPV were present in $43.9 \%, 10.3 \%$ and $24.3 \%$ of cases respectively. HCMV was associated significantly with the tumor grade, mitotic count $(P=.01)$, IDC, ER, PR, Her2/neu and molecular subtype $(P=.032, .002, .02$, $.005, .003)$ respectively. EBV was associated with the tumor size, stage and histological type $(P=.025, .005, .009)$ respectively. HPV wasn't associated with any of the clinicopathological characteristics. None of these viruses was associated with the tumor recurrence or patient death.

Conclusion: HCMV and EBV might be contributing factors for the development and behavioural alteration of breast carcinoma, representing potential tools for the detection of specific therapies for this cancer. Further studies on a larger number of cases using other techniques such as CISH for specific typing of the viruses especially HPV can add more information.
\end{abstract}

Key Words: Breast cancer, Cytomegalovirus, Epstein-Barr virus, Human papillomavirus, Immunohistochemistry

\section{INTRODUCTION}

Breast cancer is the commonest cancer and a common cause of cancer death in women all over the world accounting for $22.9 \%$ and $13.7 \%$ respectively. In Egypt, it accounted for $37.7 \%$ of women cancer and $29.1 \%$ of cancer mortality in 2008. ${ }^{[1]}$ Some risk factors have been detected such as the patient's age, family history and prolonged exposure to estrogen hormone. Sometimes an evident risk factor may be absent in 50\%-80\% of patients. ${ }^{[2]}$ So recent researches have been performed to detect further risk factors that can be associated with this cancer.

Some studies suggested a causal association between breast

${ }^{*}$ Correspondence: Rehab A Ahmed, MD; Email: rehaballah1975@gmail.com; Address: Pathology department, Faculty of medicine, Mansoura University, Mansoura, Egypt. 
cancer and viral infection like Epstein-Barr virus (EBV), mouse mammary tumor virus (MMTV), human papillomavirus (HPV) and human cytomegalovirus (HCMV). ${ }^{[3-6]}$

HCMV is one of the $\beta$-herpesvirus family with infection in $70 \%-90 \%$ of the world's population. It is reactivated periodically after latent infection in the host. ${ }^{[7]}$ The nucleic acids and proteins of HCMV have been found in many cancers such as colon, prostate, breast cancers, glioblastoma, medulloblasoma, mucoepidermoid carcinoma of the salivary glands and rhabdomyosarcoma. ${ }^{[8-10]}$ One study showed that HCMV was detected by immunohistochemical analysis in the normal epithelial cells of the breast tissue and the malignant epithelial cells of breast carcinoma but it was higher in the later. ${ }^{[6]}$ On the other hand, a recent study didn't find HCMV in breast cancer tissue. ${ }^{[11]}$

EBV is also a member of human herpes virus family and is found in about $90 \%-95 \%$ of populations mostly in children and early adolescents with different manifestations. ${ }^{[12]}$ It is also found in neoplastic diseases such as Burkitt's lymphoma, nasopharyngeal carcinoma, Hodgkin's lymphoma and gastric carcinoma. ${ }^{[13]}$ It was considered by the International Agency for Research on Cancer (IARC) as one of group 1 carcinogens. ${ }^{[14]}$ So, it has been investigated for its role in the development of breast carcinoma, where Labrecque et al. detected EBV in the epithelial cells of breast carcinoma. ${ }^{[15]}$ However, the study carried out by Deshpande et al. showed that EBV was lacking in breast carcinoma. ${ }^{[16]}$

HPV is a DNA virus which is often associated with cervical cancer in women especially the high risk types 16 and 18. It was also found in anogenital and oral carcinomas and classified as an oncovirus by IARC. ${ }^{[14]}$ After integration of the virus into the host cell genome the viral proteins such as E6 and E7 are expressed and inactivate the tumor supressor proteins P53 and Rb. ${ }^{[17]}$ The detection of HPV in breast carcinoma showed contradictory results ranged from 0 to $86 \%$ in the different studies. ${ }^{[18]}$

There are many studies that investigated HCMV, EBV and HPV in breast carcinoma with PCR that can't differentiate the viruses in tumor cells from non-epithelial cells. So, immunohistochemical analysis can localize the viral proteins either in the malignant epithelial cells and non-epithelial cells giving accurate results. ${ }^{[19-21]}$

To our knowledge, there are no studies that investigated the expression of HPV and HCMV in breast carcinoma among the Egyptian women. Regarding EBV, only 2 studies were performed and evaluated the expression of EBV in breast carcinoma in Egypt. The first was performed by Fawzy et $a l$. who evaluated EBNA1 by PCR. ${ }^{[22]}$ The second was car-

Published by Sciedu Press ried out by Zekri et al. who investigated the expression of CD21 and LMP1 antigens by immunohistochemistry, insitu hybridization and PCR. ${ }^{[23]}$ So, we aimed to detect HCMV, EBV and HPV in carcinoma of the breast by immunohistochemistry (IHC) and whether there is a relationship between such viruses and breast carcinoma's prognostic factors and outcome.

\section{Patients AND Methods}

\subsection{Data retrieval}

This retrospective study included one hundred and seven selected cases of invasive breast carcinoma that have been obtained from the Oncology Center, Faculty of Medicine, Mansoura University (OCMU), Egypt between January 2010 to December 2012. The tumors were resected by modified radical mastectomy operation. All patients received postoperative therapy; hormonal, chemo or radiotherapy. Clinicopathological and postoperative follow up data were obtained from oncology center database until August 2015. Follow up period ranged from 32-68 months with a median follow up of $37 \pm 20.51$ months.

The haematoxylin and eosin (H\&E) stained slides (cut from formalin fixed paraffin wax embedded specimens) were got back from the annals of the pathology lab in the OCMU then reviewed. Tumors were diagnosed according to WHO classification 2012 and were graded according to Nottingham grading system. ${ }^{[24,25]}$

\subsection{Tissue microarray construction}

The selected H\&E stained slides were used as a guide for selection of the regions from which samples from the paraffin blocks were obtained. Tissue microarray (TMA) was assembled manually using a mechanical pencil tip. ${ }^{[26,27]}$ Cores from the surrounding normal breast tissue were also taken as an internal control.

\subsection{Immunohistochemical staining}

The constructed TMA blocks were re-cut into 3-4 $\mu \mathrm{m} \mathrm{sec-}$ tions on slides of the coated type. After that the sections were deparaffinized followed by rehydration using alcohol of descending grades into water. Citrate buffer (at a different $\mathrm{pH}$ according to the type of the primary antibody) and heating in a microwave for 10 minutes were used for antigen retrieval. This was followed by incubation of the sections in $3 \% \mathrm{H}_{2} \mathrm{O}_{2}$ blocking medium for 5 minutes then washing with distilled water and incubation with the following primary mouse monoclonal antibodies at the ordinary temperature for one hour: oestrogen receptors (ER) (1D5; 1:50, $\mathrm{pH}=7.3$ Dako, San Jose, USA), progesterone receptors (PR) (PR 636; 1:50, pH = 7.3, Dako, San Jose, USA), Her2/neu (CB11; 
1:50, $\mathrm{pH}=7.3$ Novocastra, Newcastle, U.K), CMV late anti- normal breast duct epithelia for ER and PR. Positive external gen (1.B.225; 1:200, pH =6, Abcam, San Francisco-USA), controls were ER, PR and Her2/neu positive breast carciEBNA1(E1-2.5; 1:1000, pH = 7.6, Abcam, San Francisco, nomas for ER, PR and Her2/neu respectively. The positive USA) and HPV(K1H8; ready to use, $\mathrm{pH}=6$, Thermo Sci- external controls for HCMV, EBV and HPV were colonic carentific, Fermont, CA, USA). The mouse DAB/peroxidase REAL $^{T M}$ EnVision $^{T M}$ method (K5007, Dako, Glostrup, Denmark) was carried out for immunostaining with reference to the producer orders. The internal positive control was cinoma, nasopharyngeal carcinoma and cervical carcinoma respectively. Negative controls were assessed by replacing the primary antibody by PBS.

Table 1. Clinicopathological and immunohistochemical features of the studied breast carcinoma cases (No. and \%)

\begin{tabular}{|c|c|c|c|}
\hline & & NO. & Percentage \\
\hline \multirow{3}{*}{ Tumor grade } & G1 & 38 & $35.5 \%$ \\
\hline & G2 & 45 & $42.1 \%$ \\
\hline & G3 & 24 & $22.4 \%$ \\
\hline \multirow{3}{*}{ Mitotic count } & M1 & 48 & $44.9 \%$ \\
\hline & M2 & 54 & $50.5 \%$ \\
\hline & M3 & 5 & $4.7 \%$ \\
\hline \multirow{2}{*}{ Tumor size } & $<2 \mathrm{~cm}$ & 5 & $4.7 \%$ \\
\hline & $>2 \mathrm{~cm}$ & 102 & $95.3 \%$ \\
\hline \multirow{2}{*}{ Lymph node metastasis } & $\mathrm{N}$ & 26 & $24.3 \%$ \\
\hline & $\mathrm{P}$ & 81 & $75.7 \%$ \\
\hline \multirow{3}{*}{ Tumor stage } & Stage I & 2 & $1.9 \%$ \\
\hline & Stage II & 48 & $44.9 \%$ \\
\hline & Stage III & 57 & $53.3 \%$ \\
\hline \multirow{2}{*}{ Live or dead } & Live & 79 & $79.0 \%$ \\
\hline & Dead & 21 & $21.0 \%$ \\
\hline \multirow{2}{*}{ Metastasis or recurrence } & $\mathrm{N}$ & 76 & $71.0 \%$ \\
\hline & $\mathrm{P}$ & 31 & $29.0 \%$ \\
\hline \multirow{3}{*}{ Histological type } & IDC & 101 & $94.4 \%$ \\
\hline & ILC & 5 & $4.7 \%$ \\
\hline & Mucinous & 1 & $0.9 \%$ \\
\hline \multirow{2}{*}{ ER } & $\mathrm{N}$ & 50 & $46.7 \%$ \\
\hline & $\mathrm{P}$ & 57 & $53.3 \%$ \\
\hline \multirow{2}{*}{ PR } & $\mathrm{N}$ & 48 & $44.9 \%$ \\
\hline & $\mathrm{P}$ & 59 & $55.1 \%$ \\
\hline \multirow{2}{*}{ Her2/neu } & $\mathrm{N}$ & 86 & $80.4 \%$ \\
\hline & $\mathrm{P}$ & 21 & $19.6 \%$ \\
\hline \multirow{2}{*}{ HCMV } & $\mathrm{N}$ & 60 & $56.1 \%$ \\
\hline & $\mathrm{P}$ & 47 & $43.9 \%$ \\
\hline \multirow{2}{*}{ EBV } & $\mathrm{N}$ & 96 & $89.7 \%$ \\
\hline & $\mathrm{P}$ & 11 & $10.3 \%$ \\
\hline \multirow{2}{*}{ HPV } & $\mathrm{N}$ & 81 & $75 \%$ \\
\hline & $\mathrm{P}$ & 26 & $24.3 \%$ \\
\hline \multirow{4}{*}{ Molecular subtype } & Her2/neu & 15 & $14.0 \%$ \\
\hline & Lumial A & 44 & $41.1 \%$ \\
\hline & Luminal B & 23 & $21.5 \%$ \\
\hline & Triple negative & 25 & $23.4 \%$ \\
\hline
\end{tabular}

Note. NO.: number of cases; M1: <11 mitotic figure /10 high power fields; M2: 11-22 mitotic figure/10 high power field; M3: >22 mitotic figure/10 high power fields; N: negative cases; $\mathrm{P}$ : positive cases.

\subsection{Evaluation of immunohistochemistry}

Tumors are considered positive for ER and PR when frank staining of the nuclei is $\geq 1 \%$ of the tumor cells according to ASCO/CAP guidelines. ${ }^{[28]} \mathrm{Her} 2 /$ neu was scored according to the pattern of the membranous staining and percentage of stained tumor cells into: 0 , no or weak incomplete staining in less than $10 \%$ of the tumor cells; 1) weak incomplete staining in more than $10 \%$ of the tumor cells; 2) weak or moderate complete staining in more than $10 \%$ of the tumor cells; 3) strong and complete staining in more than $10 \%$ of 
the tumor cells. Only score 3 is taken into account as posi- cant.

tive staining. ${ }^{[29]}$ Different molecular subtypes were assessed after evaluation of Her2/neu, estrogen and progesterone receptors. ${ }^{[30]}$ Immunostaining for antiviral antibodies was considered positive if $>1 \%$ of neoplastic cells displayed distinct brown cytoplasmic and or perinuclear staining for HCMV and nuclear staining for EBNA1 and HPV.

\subsection{Statistical methods}

Data analysis was done using the computer program SPSS (Statistical package for social science) version 17.0. Quantitative statistics were calculated in the form of a mean $\pm S D$ for parametric data and as a median $\pm S D$ for non parametric data. Qualitative statistics were calculated in the form of a frequency (NO and \%). Chi-square and Fisher's exact probability tests were used for inter-group comparison of categorical data to detect the association between the virus expression and the different clinicopathological parameters. A $P$-value of $<.05$ was considered to be statistically signifi-

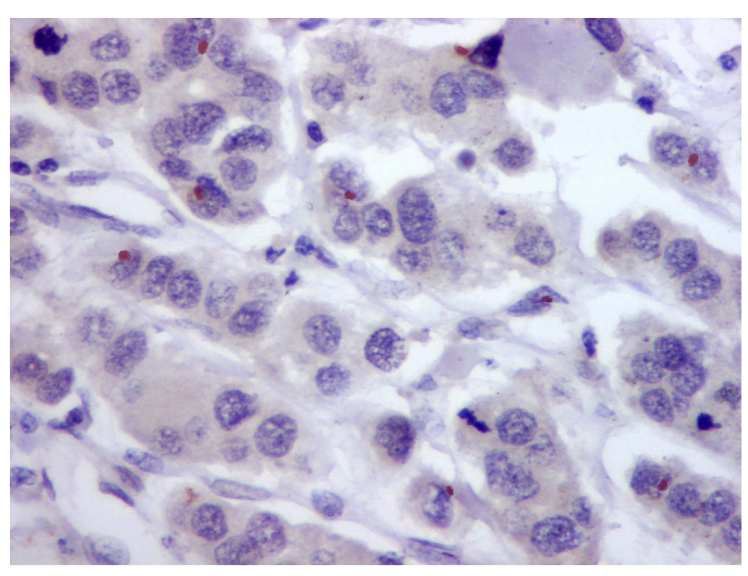

Figure 1. Immunohistochemical staining for HCMV in grade III infiltrating duct carcinoma of the breast showing brown perinuclear cytoplasmic inclusions $\times 400$

Table 2. Association of HCMV expression with the clinicopathological characteristics of breast carcinoma

\begin{tabular}{|c|c|c|c|c|c|c|}
\hline & & \multicolumn{4}{|c|}{ HCMV } & \multirow{3}{*}{$P$ value } \\
\hline & & \multicolumn{2}{|c|}{$\mathbf{N}$} & \multicolumn{2}{|l|}{$\mathbf{P}$} & \\
\hline & & NO. & Percentage & NO. & Percentage & \\
\hline \multirow{3}{*}{ Tumor grade } & G1 & 28 & $46.7 \%$ & 10 & $21.3 \%$ & \multirow{3}{*}{.01} \\
\hline & G2 & 23 & $38.3 \%$ & 22 & $46.8 \%$ & \\
\hline & G3 & 9 & $15.0 \%$ & 15 & $31.9 \%$ & \\
\hline \multirow{3}{*}{ Mitotic count } & M1 & 34 & $56.7 \%$ & 14 & $29.8 \%$ & \multirow{3}{*}{.01} \\
\hline & M2 & 25 & $41.7 \%$ & 29 & $61.7 \%$ & \\
\hline & M3 & 1 & $1.7 \%$ & 4 & $8.5 \%$ & \\
\hline \multirow{2}{*}{ Tumor size } & $<2 \mathrm{~cm}$ & 4 & $6.7 \%$ & 1 & $2.1 \%$ & \multirow{2}{*}{.27} \\
\hline & $>2 \mathrm{~cm}$ & 56 & $93.3 \%$ & 46 & $97.9 \%$ & \\
\hline \multirow{2}{*}{ Lymph node metastasis } & $\mathrm{N}$ & 13 & $21.7 \%$ & 13 & $27.7 \%$ & \multirow{2}{*}{.47} \\
\hline & $\mathrm{P}$ & 47 & $78.3 \%$ & 34 & $72.3 \%$ & \\
\hline \multirow{3}{*}{ Tumor stage } & Stage I & 1 & $1.7 \%$ & 1 & $2.1 \%$ & \multirow{3}{*}{.98} \\
\hline & Stage II & 27 & $45.0 \%$ & 21 & $44.7 \%$ & \\
\hline & Stage III & 32 & $53.3 \%$ & 25 & $53.2 \%$ & \\
\hline \multirow{3}{*}{ Histological type } & IDC & 54 & $90.0 \%$ & 47 & $100 \%$ & $.032^{*}$ \\
\hline & ILC & 5 & $8.3 \%$ & 0 & 0 & ---- \\
\hline & Mucinous & 1 & $1.7 \%$ & 0 & 0 & ---- \\
\hline
\end{tabular}

Note. "Significance between the negative and positive cases of IDC.

\section{RESULTS}

This retrospective study was carried out on 107 patients with invasive breast carcinoma. These cases included one hundred and one (94.4\%) cases with invasive ductal carcinoma (IDC) not otherwise specified (NOS), five (4.7\%) cases with invasive lobular carcinoma (ILC) and one case with mucinous carcinoma $(0.9 \%)$. The mean age of the patients was $54.6 \pm$ 12 years with an age ranging from 31 to 88 years old. The other patients' clinicopathological features are represented in Table 1.

\subsection{The relationship of HCMV expression with the clini-} copathological and immunohistochemical characteristics of breast carcinoma

HCMV was present in 47 (43.9\%) cases (see Figure 1). In positive cases, HCMV expression was limited to the tumor cells and absent in non tumor tissue and inflammatory cells. The mean age of HCMV positive cases was 54.57 years vs. 54.83 years in HCMV negative cases. There was no 
statistically significant association between age and HCMV expression $(P=.7)$. Table 2 shows that $21.3 \%, 46.8 \%$ and $31.9 \%$ of HCMV positive cases were grades I, II and III respectively with a statistically significant association between HCMV expression and the tumor grade $(P=.01)$. There was also a statistically significant association between the mitotic count (M) and HCMV infection where 29.8\%, $61.7 \%$ and $8.5 \%$ of HCMV positive cases were M1, M2 and M3 respectively $(P=.01)$. In addition, there was a statistically significant association between HCMV expression and the IDC category $(P=.032)$. On the other hand, HCMV expression didn't show any statistically significant association with the tumor size, nodal metastasis and tumor stage with $P$ values $=.27, .47$ and .08 respectively.

Table 3. Association of HCMV expression with the hormonal status, molecular subtype and patient outcome

\begin{tabular}{|c|c|c|c|c|c|c|}
\hline & & \multicolumn{4}{|c|}{ HCMV } & \multirow{3}{*}{$P$ value } \\
\hline & & \multicolumn{2}{|c|}{$\mathbf{N}$} & \multicolumn{2}{|l|}{$\mathbf{P}$} & \\
\hline & & NO. & Percentage & NO. & Percentage & \\
\hline \multirow{2}{*}{ ER } & $\mathrm{N}$ & 20 & $33.3 \%$ & 30 & $63.8 \%$ & \multirow{2}{*}{.002} \\
\hline & $\mathrm{P}$ & 40 & $66.7 \%$ & 17 & $36.2 \%$ & \\
\hline \multirow{2}{*}{ PR } & $\mathrm{N}$ & 21 & $35.0 \%$ & 27 & $57.4 \%$ & \multirow{2}{*}{.02} \\
\hline & $\mathrm{P}$ & 39 & $65.0 \%$ & 20 & $42.6 \%$ & \\
\hline \multirow{2}{*}{ Her2/neu } & $\mathrm{N}$ & 54 & $90.0 \%$ & 32 & $68.1 \%$ & \multirow{2}{*}{.005} \\
\hline & $\mathrm{P}$ & 6 & $10.0 \%$ & 15 & $31.9 \%$ & \\
\hline \multirow{4}{*}{ Molecular subtype } & Her2/neu & 2 & $3.3 \%$ & 13 & $27.7 \%$ & \multirow{4}{*}{.003} \\
\hline & Luminal A & 30 & $50 \%$ & 14 & $29.8 \%$ & \\
\hline & Luminal B & 14 & $23.3 \%$ & 9 & $19.1 \%$ & \\
\hline & Triple negative & 14 & $23.3 \%$ & 11 & $23.4 \%$ & \\
\hline \multirow{2}{*}{ Live or dead } & Live & 45 & $78.9 \%$ & 34 & $79.1 \%$ & \multirow{2}{*}{.98} \\
\hline & Dead & 12 & $21.1 \%$ & 9 & $20.9 \%$ & \\
\hline \multirow{2}{*}{ Recurrence or metastasis } & $\mathrm{N}$ & 44 & $73.3 \%$ & 32 & $68.1 \%$ & \multirow{2}{*}{.55} \\
\hline & $\mathrm{P}$ & 16 & $26.7 \%$ & 15 & $31.9 \%$ & \\
\hline
\end{tabular}

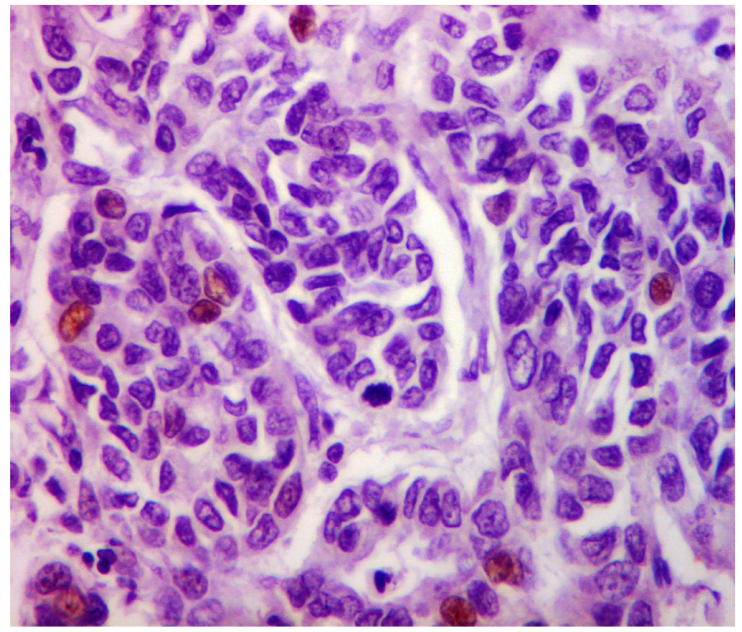

Figure 2. Immunohistochemical staining for EBV in grade II inf iltrating duct carcinoma of the breast showing brown nuclear staining $\times 400$

Table 3 shows that HCMV expression was negatively associated with ER, PR and Her2/neu expression with $P$ values $=.002,0.02 \%$ and .005 respectively. A statistically significant association was also found between HCMV expression and molecular subtypes with $P$ value .003 . However, no statistically significant association was found between the 12 expression of HCMV and patient death or tumor recurrence $(P=.98$ and .55$)$ respectively.

\subsection{The relationship of EBV expression with the clinico- pathological and immunohistochemical characteris- tics of breast carcinoma}

It was found that EBV was expressed in 11 (10.3\%) cases (see Figure 2). The expression was found only in the malignant epithelial cells and absent in the surrounding normal breast tissue or lymphocytes infiltrating the tumor stroma. The mean age in EBV positive cases was $56.82 \pm 14.62$ years compared to $54.44 \pm 11.74$ years in EBV negative cases with no statistically significant association between the age and EBV expression $(P=.5)$. As shown in Table 4, EBV expression shows a statistically significant association with a large tumor size and a higher tumor stage $(P=.025$ and .005) respectively. EBV expression also showed a statistically significant association with the histological type $(P=$ .009 ), where $90.9 \%$ of EBV positive cases were of IDC type. On the other hand, there was no significant association with the histological grade, mitotic count or metastasis in lymph node $(P=.15 . .4$ and .08$)$ respectively. From Table 5, the expression of EBV doesn't show any significant association with ER, PR, Her2/neu, molecular subtype, patient death or 
tumor recurrence with $P$ values $=.9, .2, .08, .56, .8$ and .36 respectively.

\subsection{The relationship of HPV expression with the clinico- pathological and immunohistochemical characteris- tics of breast carcinoma}

HPV was found to be expressed in 26 (24.3\%) cases (see Figure 3). The expression was limited to the tumor tissue but it was absent in the surrounding normal tissue. The mean age of HPV-positive cases was 56.77 years versus 54.01 years in HPV-negative cases with no statistically significant association $(P=.5)$. Although grade 2 and grade 3 together were the highest among HPV-positive cases, there was no significant association between the tumor grade and HPV $(P=$ $.8)$. It was noticed that tumor size more than $2 \mathrm{~cm}$ accounted for $96.2 \%$ of HPV-positive cases but it wasn't significantly associated with the virus expression $(P=.8)$. The same was found with the lymph node metastasis where cases with lymph node metastasis represented $69.2 \%$ of HPV-positive cases with no significant association $(P=.37)$. Stage 2 and 3 accounted for $61.5 \%$ and $38.3 \%$ of HPV-positive cases respectively but with no significant association with the virus expression $(P=.12)$. Regarding the association with ER, PR,
Her2/ neu and the molecular subtypes, there was no significant association with HPV expression $(P=.7, .76, .95$ and .36) respectively. There was also no significant association between HPV expression and the tumor recurrence or patient death $(P=.44$ and .7$)$ respectively.

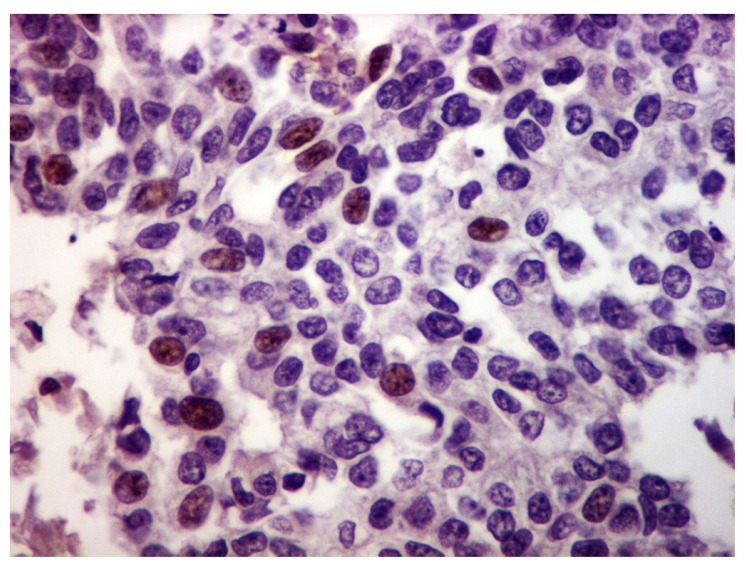

Figure 3. Immunohistochemical staining for HPV in grade II infiltrating duct carcinoma of the breast showing brown nuclear staining $\times 400$

Table 4. Association of EBV with the clinicopathological characteristics

\begin{tabular}{|c|c|c|c|c|c|c|}
\hline & & \multicolumn{4}{|c|}{$\overline{\text { EBV }}$} & \multirow{3}{*}{$P$ value } \\
\hline & & \multicolumn{2}{|l|}{$\mathbf{N}$} & \multicolumn{2}{|l|}{$\mathbf{P}$} & \\
\hline & & NO. & Percentage & NO. & Percentage & \\
\hline \multirow{3}{*}{ Tumor grade } & G1 & 35 & $36.5 \%$ & 3 & $27.3 \%$ & \multirow{3}{*}{.15} \\
\hline & G2 & 42 & $43.8 \%$ & 3 & $27.3 \%$ & \\
\hline & G3 & 19 & $19.8 \%$ & 5 & $45.5 \%$ & \\
\hline \multirow{3}{*}{ Mitotic count } & M1 & 45 & $46.9 \%$ & 3 & $27.3 \%$ & \multirow{3}{*}{.4} \\
\hline & M2 & 47 & $49.0 \%$ & 7 & $63.6 \%$ & \\
\hline & M3 & 4 & $4.2 \%$ & 1 & $9.1 \%$ & \\
\hline \multirow{2}{*}{ Tumor size } & $<2 \mathrm{~cm}$ & 3 & $3.1 \%$ & 2 & $18.2 \%$ & \multirow{2}{*}{.025} \\
\hline & $>2 \mathrm{~cm}$ & 93 & $96.9 \%$ & 9 & $81.8 \%$ & \\
\hline \multirow{2}{*}{ Lymph node metastasis } & $\mathrm{N}$ & 21 & $21.9 \%$ & 5 & $45.5 \%$ & \multirow{2}{*}{.08} \\
\hline & $\mathrm{P}$ & 75 & $78.1 \%$ & 6 & $54.5 \%$ & \\
\hline \multirow{3}{*}{ Tumor stage } & Stage I & 2 & $2.1 \%$ & 0 & $0.0 \%$ & \multirow{3}{*}{.005} \\
\hline & Stage II & 38 & $39.6 \%$ & 10 & $90.9 \%$ & \\
\hline & Stage III & 56 & $58.3 \%$ & 1 & $9.1 \%$ & \\
\hline \multirow{3}{*}{ Histological type } & IDC & 91 & $94.8 \%$ & 10 & $90.9 \%$ & \multirow{3}{*}{.009} \\
\hline & ILC & 5 & $5.2 \%$ & 0 & 0 & \\
\hline & Mucinous carcinoma & 0 & 0 & 1 & $9.1 \%$ & \\
\hline
\end{tabular}

\section{Discussion}

This study was carried out to investigate the existence of HCMV, EBV and HPV in invasive carcinoma of the breast and their association with its prognostic factors by IHC which has been constantly debated over the past decade.

HCMV was detected in $43.9 \%$ of our cases. One study de- tected the virus in $7.4 \%$ of cases by PCR but they didn't find any association with the clinicopathological parametrs and patient survival. ${ }^{[19]}$ The latter study explained the absence of correlation with prognostic parameters by the hit and run theory. On the other hand, the present study revealed a statistically significant negative association with ER, PR 
and Her2/neu and the molecular subtype where the higher expression was among the Her2- positive and triple negative cases. It was also found to be associated significantly with the tumor grade and the mitotic count. Others found the virus proteins in $100 \%$ of cases and in the epithelial cells of metastasis in the sentinel lymph nodes suggesting its role in development of breast cancer and its metastasis. ${ }^{[31]}$ It has been found that there is an association between HCMV and lower disease free and overall survival times. ${ }^{[5]}$ However, we found that HCMV wasn't associated with tumor recurrence or patient death. The virus wasn't detected in non - tumor tissue or inflammatory cells in our study which is consistent with the results detected by Taher et al. ${ }^{[31]}$ In addition, others didn't find the virus in the fibroadenoma tissue. ${ }^{[19]}$

Table 5. Association of EBV expression with the hormonal status, molecular subtype and patient outcome

\begin{tabular}{|c|c|c|c|c|c|c|}
\hline & & \multicolumn{4}{|c|}{ EBV } & \multirow{3}{*}{$P$ value } \\
\hline & & \multicolumn{2}{|l|}{$\mathbf{N}$} & \multicolumn{2}{|l|}{$\mathbf{P}$} & \\
\hline & & NO. & Percentage & NO. & Percentage & \\
\hline \multirow{2}{*}{ ER } & $\mathrm{N}$ & 45 & $46.9 \%$ & 5 & $45.5 \%$ & \multirow{2}{*}{.9} \\
\hline & $\mathrm{P}$ & 51 & $53.1 \%$ & 6 & $54.5 \%$ & \\
\hline \multirow{2}{*}{ PR } & $\mathrm{N}$ & 45 & $46.9 \%$ & 3 & $27.3 \%$ & \multirow{2}{*}{.2} \\
\hline & $\mathrm{P}$ & 51 & $53.1 \%$ & 8 & $72.7 \%$ & \\
\hline \multirow{2}{*}{ Her2/neu } & $\mathrm{N}$ & 75 & $78.1 \%$ & 11 & $100.0 \%$ & \multirow{2}{*}{.08} \\
\hline & $\mathrm{P}$ & 21 & $21.9 \%$ & 0 & 0 & \\
\hline \multirow{4}{*}{ Molecular subtype } & Her2/neu & 15 & $15.6 \%$ & 0 & 0 & \multirow{4}{*}{.56} \\
\hline & Luminal A & 39 & $40.6 \%$ & 5 & $45.5 \%$ & \\
\hline & Luminal B & 20 & $20.8 \%$ & 3 & $27.3 \%$ & \\
\hline & Triple negative & 22 & $22.9 \%$ & 3 & $27.3 \%$ & \\
\hline \multirow{2}{*}{ Live or dead } & Live & 70 & $78.7 \%$ & 9 & $81.8 \%$ & \multirow{2}{*}{.8} \\
\hline & Dead & 19 & $21.3 \%$ & 2 & $18.2 \%$ & \\
\hline \multirow{2}{*}{ Recurrence or metastasis } & $\mathrm{N}$ & 67 & $69.8 \%$ & 9 & $81.8 \%$ & \multirow{2}{*}{.36} \\
\hline & $\mathrm{P}$ & 29 & $30.2 \%$ & 2 & $18.2 \%$ & \\
\hline
\end{tabular}

EBV has been suggested to be associated with breast cancer indicated by detection of the virus in breast milk, presence of some EBV associated lymphomas in the breast and that breast cancer has epidemiological similarities to young adult Hodgkin's lymphoma. ${ }^{[20]}$ Immunohistochemical study of EBNA1 revealed different results ranged from $0 \%, 4 \%, 25 \%$, $37 \%, 42 \%$ and $51 \% .{ }^{[20]}$ Our study found EBV in $11(10.3 \%)$ cases. One Egyptian study detected EBV in $25 \%$ of the breast carcinoma specimens stained for EBNA-1 in the Egyptian women but by PCR analysis. ${ }^{[2]}$ The difference among the different studies can be attributed to the difference in the studied clones, the studied antigens (EBNA1, EBNA2 or LMP1), the genetic predisposition or due to difference in the geographical distribution. The expression of EBV has been found in 5\%-30\% of the tumor cells which is consistent with ours. ${ }^{[32]}$ It has also been demonstrated that the virus expression ranged from $5 \%-50 \%$ by another study. ${ }^{[33]}$ The different proportion of stained tumor cells can be attributed to that breast carcinomas have highly heterogenous genomic content and distribution. So, it is suggested that EBV might play a role in the development of breast cancer in association with other co-factors but not a primary etiological agents. ${ }^{[20]}$

It was found that EBV is associated with aggressive tumors where Bonnet et al. found a significant association with high grade tumors, ER-negative tumors and presence of the virus in metastases of EBV positive primary tumors. ${ }^{[32]}$ Our study, on the other hand didn't find any significant association with the tumor grade, lymph node metastasis, the hormonal status, the molecular subtype, tumor recurrence or patient death. However, there was a significant association with the tumor size (supporting the role of the virus in tumor proliferation), the tumor stage and the histological type where higher expression was found in infiltrating duct carcinoma than infiltrating lobular carcinoma. Others found that the higher expression of EBV was present in the medullary than the lobular carcinoma. ${ }^{[34]}$

EBV tends to infect young persons of both sexes suggesting a genetic predisposition or early life exposure. It also affects older ages if the immune system is diminished. ${ }^{[20]}$ It has been reported that EBV positivity is higher in women less than 50 years than those older than 50 years which isn't consistent with ours. ${ }^{[35]}$ The virus wasn't found in the surrounding normal tissue or the lymphocytes infiltrating the tumor stroma in our cases, which is consistent with other studies suggesting the role of EBV in breast carcinoma. ${ }^{[15,33,35]}$

HPV was present in $26(24.3 \%)$ cases in our study. This agrees with the study carried out by Pereira et al. where HPV 
was present in $26 \%$ of cases but was detected by PCR. ${ }^{[36]}$ In a study carried out in Kuwait, HPV was found in $16.7 \%$ of cases by IHC and $35.4 \%$ by chromogenic insitu hybridization (CISH). They also didn't find a statistically significant association with the prognostic factors, which is consistent with our results. ${ }^{[37]}$ One study stated that the prevalence of HPV varied from $4 \%$ in Mexican to $86 \%$ in American women. ${ }^{[38]}$ This wide difference among literatures could be attributed to the methods of detection where most studies utilized PCR technique with the higher sensitivity but low specificity as compared to CISH and IHC. ${ }^{[37]}$ The expression of HPV was found only in the tumor tissue and absent in the surrounding normal tissue in our study which agrees with the previous studies. ${ }^{[37,38]}$ However, one Turkish study detected the virus in the normal tissue but at a lower level. ${ }^{[39]}$ On the other hand, Eslamifar et al. didn't detect HPV in all tested carcinomas or the normal breast tissue. ${ }^{[40]}$

\section{Conclusion}

The present results demonstrated HCMV, EBV and HPV in a fraction of breast carcinomas in Egyptian women (OCMU) by IHC method, which is more accurate than the PCR technique in distinguishing the tumor cells from the nontumor tissue and the inflammatory cells. HCMV was the most common in our cases and it was associated with the tumor grade, mitotic count and the hormonal status. Although EBV was the least expressed one, was associated with tumor size, tumor stage and the histological type. The previous findings indicate that HCMV and EBV might be contributing factors for development and behavioural alteration of breast carcinoma supported by their restriction to the epithelial cells. In addition, these results represent potential tools for the development of specific therapies such as immunotherapeutic strategies based on EBV specific cytotoxic T cells which are recently being used for the treatment of Hodgkin's lymphoma and nasopharyngeal carcinoma positive for EBV. Although HPV was present in breast carcinomas, it wasn't associated with the clinicopathological characters of this carcinoma which requires further investigations.

\section{RECOMMENDATIONS}

Further studies on a larger number of cases obtained from the different oncology centers in Egypt are recommended to obtain more accurate results to be compared with the worldwide data. In addition, using other techniques such as CISH for specific typing of the viruses or using different methods such as PCR, CISH and IHC at the same time and compare all data can add more information. Understanding the association between these viruses and breast carcinoma is important to identify women at risk for this cancer and those who can benefit from the use of antiviral therapy as a prophylactic therapy or as a therapy for a residual disease. In future, it would be good to carry out the additional studies by monitoring breast cancer incidence amongst women vaccinated against these viruses.

\section{Conflicts OF InTEREST Disclosure}

No potential conflicts of interest are disclosed.

\section{REFERENCES}

[1] Ferlay J, Shin HR, Bray F, et al. Estimates of Worldwide Burden of Cancer in 2008: GLOBOCAN 2008. International Journal of Cancer. 2010; 127: 2893-917. PMid:21351269. http://dx.doi.org/10. $1002 /$ ijc. 25516

[2] Andres CK, Carey LA. Biology, metastatic patterns and treatment of patients with triple-negative breast cancer. Clin Breast Cancer. 2009; 9 (2): 73-81. PMid:19596646. http://dx.doi.org/10.3816/C BC. 2009.s.008

[3] Joshi D, Quadri M, Gangane N, et al. Association of Epstein Barr virus infection (EBV) with breast cancer in rural Indian women. Plos one. 2009; 4: e8180. PMid:19997605. http://dx.doi.org/10. 1371/journal.pone. 0008180

[4] Melana SM, Nepomnaschy I, Hasa J, et al. Detection of human mammary tumor virus proteins in human breast cancer cells. J Virol Methods. 2010; 163: 157-61. PMid:19781575. http://dx.doi.o $\mathrm{rg} / 10.1016 / \mathrm{j} \cdot \mathrm{j}$ viromet. 2009.09.015

[5] Tsai JH, Hsu CS, Tsai CH, et al. Relationship between viral factors, axillary lymph node status and survival in breast cancer. J Cancer Res Clin Oncol. 2007; 133: 13-21. PMid:16865407. http: //dx.doi.org/10.1007/s00432-006-0141-5
[6] Harkins LE, Matlaf LA, Soroceanu L, et al. Detection of human cytomegalovirus in normal and neoplastic breast epithelium. Herpesvirida. 2010; 1(1): 8. PMid:21429243. http://dx.doi.org/1 $0.1186 / 2042-4280-1-8$

[7] Britt WJAC. Cytomegalovirus. In Fields BN. Knipe DM, Howley PM. editors Fields Virology. New York: Lippincotti and Wilkins 1996.

[8] Soroceanu L, Cobbs CS. Is HCMV a tumor promoter? Virus research. 2011; 157: 193-203. PMid:21036194. http://dx.doi.o $\mathrm{rg} / 10.1016 / \mathrm{j}$. virusres . 2010.10.026

[9] Melnick M, Sedghizadeh PP, Allen CM, et al. Human cytomegalovirus and mucoepidermoid carcinoma of salivary glands. Cell-specific localization of active viral and oncogenic signaling proteins is confirmatory of a causal relationship. Experimental and molecular pathology. 2012; 92(1):181-125. PMid:22101257. http://dx.doi.org/10.1016/j.yexmp.2011.10.011

[10] Price RL, Bingmer K, Harkins L, et al. Cytomegalovirus infection leads to pleomorphic rhabdomyosarcomas in trp53+/-mice. Cancer research. 2012; 72: 5669-574. PMid:23002204. http://dx.doi.o rg/10.1158/0008-5472. CAN-12-2425

[11] Antonsson A, Bialasiewicz S, Rockett RJ, et al. Exploring the prevalence of ten polyomaviruses and two herpes viruses in breast 
cancer. PLoS One. 2012; 7(8): e39842. PMid:22916092. http: //dx.doi.org/10.1371/journal.pone.0039842

[12] Schooley RT. Epstein Barr virus (infectious mononucleosis). In: Mandell.Douglas and Bennett's principles and practice of infectious diseases. Churchill Livingstone, New York. 1995: 1364-77.

[13] Crawford DH. Biology and disease associations of Epstein-Barr virus. Philos Trans R Soc Lond B Biol. 2001; 356: 461-73. PMid:11313005. http://dx.doi.org/10.1098/rstb.2000.0783

[14] IARC Working Group on the Evaluation of Carcinogenic Risks to Humans. Human papillomaviruses. IARC monographs on the evaluation of carcinogenic risks to humans / World Health Organization, International Agency for Research on Cancer. 2007; 90: 1-636.

[15] Labrecque LG, Barnes DM, Fentiman IS, et al. Epstein Barr virus in epithelial cell tumors: a breast carcinoma study. Carcinoma Res. 2001; 55: 39-45.

[16] Deshpande CG, Badve S, Kidwai N, et al. Lack of expression of the Epstein-Barr virus (EBV) gene products, EBERs, EBNA1, LMP1 and LMP2A, in breast carcinoma cells. Lab Invest. 2002; 82: 1193 9. PMid:12218080. http://dx.doi.org/10.1097/01.LAB.00 00029150.90532 .24

[17] Wang T, Chang P, Wang L, et al. The role of human papillomavirus infection in breast cancer. Med Oncol. 2012; 29(1): 4855. PMid:21318737. http://dx.doi.org/10.1007/s12032-0 10-9812-9

[18] Simoes PW, Medeiros LR, Simoes Pires PD, et al. Prevalence of human papillomavirus in breast cancer: a systematic review. Int $\mathrm{J}$ Gynecol Cancer. 2012; 22(3): 343-7. http://dx.doi .org/10.10 97/igc.0b013e31823c712e

[19] TUtrera-Barillas D, Valdez-Salazar H, Gomez-Rangel D, et al. Is human cytomegalovirus associated with breast cancer progression? Infectious Agents and Cancer. 2013; 8: 12. PMid:23557440. http://dx.doi.org/10.1186/1750-9378-8-12

[20] Glaser SL, Hsu JL, Gulley ML. Epstein-Barr virus and breast cancer: State of the Evidence for Viral carcinogenesis. Cancer Epidemiol Biomarkers Prev. 2004; 13(5): 688-97. PMid:15159298.

[21] Heng B, Glenn WK, Ye Y, et al. Human Papilloma virus is associated with breast cancer. British Journal of cancer. 2009; 101: 1345 50. PMid:19724278. http://dx.doi.org/10.1038/sj.bjc.66 05282

[22] Fawzy S, Sallam M, Awad NM. Detection of Epstein-Barr virus in breast carcinoma in Egyptian women. Clin Biochem. PMid:18258188. http://dx.doi.org/10.1016/j.clinbioch em. 2007.12.017

[23] Zekri AN, Bahnassy AA, Mohamed WS, et al. Epstein-Barr virus and breast cancer: Epidemiological and Molecular study on Egyptian and Iraqi women. Journal of the Egyptian National cancer institute. PMid:22929918. http://dx.doi.org/10.1016/j.jnci. 2012.06.001

[24] Lakhani SR, Ellis IO, Schnitt SJ, et al. WHO classification of tumors of the breast, 4th ed. Lyon, IARC, Press 2012.

[25] Eltson CW, Ellis IO. Pathological prognostic factors in breast cancer. The value of histological grades in breast cancer. Experience from a large study with long- term follow-up. Histopathology. 1991; 19: 403-10. http://dx.doi.org/10.1111/j.1365-2559.1991 .tb00229.x
[26] Shebl AM, Zalata KR, Amin MM, et al. An inexpensive method of small paraffin tissue microarrays using mechanical pencil tips. Diagn Pathol. 2011; 1(6): 117. PMid:22132713. http://dx.doi.org/1 $0.1186 / 1746-1596-6-117$

[27] Foda AM. No-cost Manual Method for Preparation of Tissue Microarrays Having High Quality Comparable to Semiautomated Methods. Appl Immunohistochem Mol Morphol. 2012; 21: 271-4.

[28] Deyarmin B, Kane JL, Valente A L, et al. Effect of ASCO/CAP Guidelines for Determining ER Status on Molecular Subtype Ann Surg Oncol. 2013; 20: 87-93.

[29] Wolff AC, Hammond EH, Hicks DG, et al. Recommendations for Human Epidermal Growth Factor Receptor 2 Testing in Breast Cancer: American Society of Clinical Oncology/College of American Pathologists Clinical Practice Guideline Update. J Clin Oncol. 2013; 31(31): 3997-4013. PMid:24101045. http://dx.doi.org/10.12 00/JC0.2013.50.9984

[30] Sandhu R, Parker J, Jones W, et al. Microarray-based gene expression profiling for molecular classification of breast cancer and identification of new targets for therapy. Lab Med. 2010; 41(6): 364-72. http://dx.doi.org/10.1309/LMLIKOVIE3CJKOWD

[31] Taher C, de Boniface J, Mohammed A, et al. High prevalence of Human Cytomegalovirus proteins and Nucleic acid in primary breast cancer and metastatic sentinel Lymph node. PLOS one. 2013; 10: 1371. http://dx.doi.org/10.1371/journal . pone. 0056795

[32] Bonnet M, Guinebretiere JM, Kremmer E, et al. Detection of EpsteinBarr virus in invasive breast cancers. JNatl Cancer Inst. 1999; 91: 1376-81. http://dx.doi.org/10.1093/jnci/91.16.1376

[33] Khabaz MN. Association of Epstein-Barr virus infection and breast carcinoma. Arch Med Sci. 2013; 9(4): 745-51. PMid:24049539. http://dx.doi.org/10.5114/aoms.2013.37274

[34] Murray PG. Epstein-Barr virus in breast carcinoma: artifact or etiological agent? J Pathol. 2006; 209: 430-5. PMid:16906594. http://dx.doi.org/10.1002/path. 2032

[35] Chu PG, Chang K, Chen Y, et al. No significant association of Epstein Barr Virus infection with invasive breast carcinoma. Am J Pathol. 2001; 159: 571-8. http://dx.doi.org/10.1016/S0002 -9440 (10) 61728-2

[36] Pereira Suarez AL, Lorenzetti MA, Lucano RG, et al. Presence of Human Papilloma Virus in a series of Breast Carcinoma from Argentina.Plos one. 2013; 8(4): e61613. PMid:23637866. http: //dx.doi.org/10.1371/journal.pone.0061613

[37] Francis IM, AL-Ayadhy B, Al-Awadhi S, et al. Prevalence and correlation of Human Papilloma virus and its types with prognostic markers in Patients with Invasive Ductal carcinomaof the breast in Kuwait. Clinical and Basic Research. 2013; 13(4): 527-33.

[38] Heng B, Glenn WK, Ye Y, et al. Human papilloma virus is associated with breast cancer. Br J Cancer. 2009; 101: 1345-50. PMid:19724278. http://dx.doi.org/10.1038/sj.bjc. 6605282

[39] Gumus M, Yumuk PF, Salepci T, et al. HPV DNA frequency and subset analysis in human breast cancer patients' normal and tumoral tissue samples. J Exp Clin Cancer Res. 2006; 25: 515-21. PMid: 17310842 .

[40] Eslamifar A, Ramezani A, Azadmanesh K, et al. Assessment of the Association between Human Papillomavirus Infection and Breast Carcinoma. Iranian journal of Pathology. 2015: 10(1); 41-6. 